\title{
Active Carbon Preparation from Treads of Tire Waste for Dye Removal in Waste Water
}

\author{
Michael R. Nunes, ${ }^{a}$ Giordana M. Perez, ${ }^{b}$ Lara F. Loguercio, ${ }^{b}$ Eliete W. Alves, ${ }^{b}$ \\ Neftali L. V. Carreño, ${ }^{b}$ Jorge L. Martins ${ }^{b}$ and Irene T. S. Garcia*,a \\ ${ }^{a}$ Instituto de Química, Universidade Federal do Rio Grande do Sul, Av. Bento Gonçalves 9500, \\ CP 15003, 91501-970 Porto Alegre-RS, Brazil \\ ${ }^{b}$ Departamento de Química Analítica e Inorgânica, Instituto de Química e Geociências, \\ Universidade Federal de Pelotas, Campus Capão do Leão, 96010-900 Pelotas-RS, Brazil
}

\begin{abstract}
Bandas de rodagem de sucatas de pneus apresentam baixos teores de cargas inorgânicas e grande quantidade de negro de fumo em sua formulação. Neste trabalho, esse material foi tratado com hidróxido de potássio e cloreto de zinco e, em seguida, realizou-se a pirólise a 500 e $700{ }^{\circ} \mathrm{C}$. Foi investigado o desempenho dos produtos na remoção dos corantes azul de metileno e alaranjado de metila em condições ambientais de $\mathrm{pH}$ e concentração. Carbonos obtidos com KOH e pirólise a $700{ }^{\circ} \mathrm{C}$ apresentam uma melhor capacidade de adsorção. A simulação deste processo permitiu a caracterização dos gases que contribuem para o desenvolvimento da superfície. Os produtos obtidos apresentam estrutura mesoporosa e estreita distribuição no tamanho de partícula. A presença de contaminantes oriundos desses carbonos foi investigada em meio aquoso. A ausência de zinco e enxofre e o excelente desempenho para remoção de corantes fazem esses materiais úteis no tratamento de água.
\end{abstract}

Treads of scrap tires present low contents of inorganic fillers and a large amount of carbon black. In this work, this material was treated with potassium hydroxide and zinc chloride followed by pyrolysis at 500 and $700{ }^{\circ} \mathrm{C}$. The ability to remove methylene blue and methyl orange were investigated under environmental conditions of $\mathrm{pH}$ and concentration. Carbons obtained with $\mathrm{KOH}$ at $700{ }^{\circ} \mathrm{C}$ present superior adsorption capacity. A simulation of this process permitted the characterization of the gases which contributed to surface development. The obtained products present a mesoporous structure and narrow particle size distribution. The presence of contaminants originated from these carbons was investigated in the aqueous media. The absence of zinc and sulfur releasing and the excellent ability to remove organic dye make these materials useful in the treatment of waste water.

Keywords: pyrolysis, active carbon, tire tread, recycling, dye removal

\section{Introduction}

The disposal of automotive scrap tires is a challenging problem and different processes for recycling have been proposed. Balckman and Palma ${ }^{1}$ focused as risks, tire piles and mosquito-borne diseases, the contribution of scrap tires to local solid waste disposal problems.

The recycling include physical ${ }^{2,3}$ biological $^{4}$ and chemical processes ${ }^{5,6}$ that permit obtaining new materials, such as small molecular weight molecules and plasticizers.

*e-mail: irene@iq.ufrgs.br
One of the most promising applications is the obtainment of carbons with a high specific surface area that are used as adsorbents, as catalyst support in organic synthesis and in the storage of hydrogen and natural gas. ${ }^{7,8}$ The use of carbon as adsorbent for organic dyes ${ }^{9-12}$ is a good way for cleaning waste water, but attention should be paid to avoid impurities of the used carbons. These contribute for additional water pollution. Photooxidation is an excellent technology to oxidize organics, however its efficiency is conditioned to the light penetration in waste water and, organic dyes strongly absorb light in the ultraviolet and visible region of spectrum. ${ }^{13}$ In this way, the previous dye removal improves the penetration of light in waste water and the efficiency of the photooxidation process. 
These applications have driven many authors to investigate and propose conditions for producing active carbons from scraps tires, ${ }^{8-12,14-24}$ as well as other organic materials. ${ }^{25-28}$

Time, temperature and steps involved in the process are important factors that have to be taken into account when choosing the best way of recycling. The significant processes to produce adsorbent carbons are reported in the following paragraphs.

Carbons can be obtained through direct pyrolysis of tire shreds under inert atmosphere ${ }^{11,24,29}$ or through chemical activation with dehydration agents, such as phosphoric, sulfuric and nitric acids, zinc chloride and alkaline metal compounds, followed by pyrolysis up to $900{ }^{\circ} \mathrm{C}$, under inert atmosphere. . $^{15,17,28}$

Mui et al. ${ }^{12}$ also report the pyrolysis with an activating agent followed by physical activation.

The most studied way to obtain carbons is through pyrolysis under inert atmosphere followed by activation with $\mathrm{CO}_{2}$ or oxidizing gases to increase the specific surface area. ${ }^{20,30,31}$

Pyrolysis of scrap tires followed by activation with $\mathrm{H}_{2} \mathrm{O}, \mathrm{CO}_{2}$ and $\mathrm{N}_{2}$ gas mixtures at $970{ }^{\circ} \mathrm{C}$ produces carbons with specific surface areas varying from $430-500 \mathrm{~m}^{2} \mathrm{~g}^{-1} .^{20,21}$ Suuberg and Aarna ${ }^{19}$ suggest that this phenomenon is based in the fact that some porosity formed under oxidizing conditions could be associated with the original carbon black particles in the tires. Pyrolysis of rubber scrap under a nitrogen flow at $700{ }^{\circ} \mathrm{C}$ produces carbons with an average surface area of $81 \mathrm{~m}^{2} \mathrm{~g}^{-1}$ which increases to $272 \mathrm{~m}^{2} \mathrm{~g}^{-1}$ when activated with $900{ }^{\circ} \mathrm{C}$ steam during $3 \mathrm{~h} \cdot{ }^{22,23}$ When the adsorption characteristics are concerned, the specific surface area is just one factor that affects the performance of the carbons. The nature of the pores, the relation between the pore diameter and the size of the adsorbed species, $\mathrm{pH}$, temperature and the characteristics of the carbon surface are also very important. ${ }^{32-34}$ The performance of a carbon in removing small molecules, methane, $\mathrm{CO}_{2}$ and dyes are significantly different. ${ }^{7,27}$

In addition, the studies reported above show the subject is also controversial when the final characteristics of the carbons produced at similar conditions are concerned. The heterogeneous rubber composition of the scrap tires was attributed as responsible for this fact. The rubber composition of the lateral parts is different from the composition of the treads. This special part of the tire is composed of good quality black carbon, N220 classified according ASTM D 1765 (Standard Classification System for Carbon Blacks Used in Rubber Products), and the polymer is poor in inorganic additives making it an excellent raw material for the production of active carbons.
Our previous work has shown that the use of treads instead of the entire tire rubber composition makes the pore size distribution more homogeneous, contributing to the increase in quality of the obtained carbons. ${ }^{14}$

In this work the focus of our study is the preparation and characterization of the chemical structure and the performance of the active carbons from triturated treads of scrap of tires. A single activation step with potassium hydroxide and zinc chloride was used. Chemical and morphological characteristics of the produced material and the effect of the activating agent on the specific surface area of the carbons are discussed.

The capacity to remove two chemically different water soluble dyes was determined: methylene blue, a cationic dye largely used in the textile industry, analytical chemistry and medicine, and methyl orange (4-dimethylaminoazobenzene-4'-sulfonic acid sodium salt) an anionic dye, that is used in the textile, printing, paper manufacturing, and pharmaceutical industries. Royer et al. ${ }^{27}$ determined $\mathrm{pH} 8.5$ as the optimum condition for organic pyrolysed materials to adsorb methylene blue dye. In this work, the capacity to remove these dyes was investigated without the addition of chemicals to increase $\mathrm{pH}(\mathrm{pH} 7.0)$.

\section{Experimental}

\section{Sample preparation}

The used treads of tire waste were composed of $13.0 \%$ poly(cis-isoprene), $16.8 \%$ poly(styrene-butadiene), $21.8 \%$ poly(cis-butadiene), $29.5 \%$ carbon black, $13.3 \%$ oil, $0.5 \%$ estearic acid, $1.0 \%$ sulfur, $2 \% \mathrm{ZnO}, 0.5 \%$ crosslinking organic accelerator and $1.5 \%$ of antirust $(\mathrm{m} / \mathrm{m})$, provided by VIPAL S.A. After triturating, particles with diameters lower than $300 \mu \mathrm{m}$ were mixed with the activation agents in a ratio of $1: 1(\mathrm{~m} / \mathrm{m})$, stirred for $30 \mathrm{~min}$ and dried at $110^{\circ} \mathrm{C}$ for $2 \mathrm{~h}$. Subsequently, the samples were pyrolyzed to the utmost temperatures (shown in Table 1), maintained at these temperatures for $2 \mathrm{~h}$ and afterwards, cooled to room temperature. The pyrolysis took place in a horizontal tube furnace, with a $130 \mathrm{~cm}^{3} \mathrm{~min}^{-1}$ nitrogen flow. The heating and cooling rates were $20^{\circ} \mathrm{C} \mathrm{min}^{-1}$.

Table 1. Pyrolysis conditions and weight losses related to the original mixture

\begin{tabular}{lccc}
\hline $\begin{array}{l}\text { Sample } \\
\text { number }\end{array}$ & $\begin{array}{c}\text { Activating } \\
\text { agent }\end{array}$ & $\begin{array}{c}\text { Pyrolysis } \\
\text { temperature } /{ }^{\circ} \mathrm{C}\end{array}$ & $\begin{array}{c}\text { Weight } \\
\text { loss } / \%\end{array}$ \\
\hline 1 & $\mathrm{KOH}$ & 500 & 50.4 \\
2 & $\mathrm{ZnCl}_{2}$ & 500 & 70.0 \\
3 & $\mathrm{KOH}$ & 700 & 40.0 \\
4 & $\mathrm{ZnCl}_{2}$ & 700 & 44.4 \\
\hline
\end{tabular}


The pyrolysis products were stirred in $1 \mathrm{~mol} \mathrm{~L}^{-1} \mathrm{HCl}$ $(50 \% \mathrm{~m} / \mathrm{v})$ for $60 \mathrm{~min}$ to remove the sulfur and zinc, constituents of the pristine tire elastomeric composition, as well as the zinc from the added activating agent (Table 1, samples 2 and 4). The carbonaceous products were washed with hot water until $\mathrm{pH} 7.0$ and dried at $120^{\circ} \mathrm{C}$ for $2 \mathrm{~h}$.

\section{Sample characterization}

The carbonaceous materials were characterized according to their chemical composition, structural and textural properties and the capacity for removing methylene blue and methyl orange dyes.

Water and acid solutions ( $\mathrm{pH} 5$ ) were kept in contact with the pyrolysis products for $2 \mathrm{~h}$ and tested against $\mathrm{Pb}\left(\mathrm{CH}_{3} \mathrm{COO}\right)_{2} 0.5 \mathrm{~mol} \mathrm{~L}^{-1}$ and potassium ferrocyanide $0.1 \mathrm{~mol} \mathrm{~L}^{-1}$ in order to determine the presence of soluble sulfur and zinc, respectively. These tests are important since these carbons can be used in waste water treatment.

The Raman spectra were obtained with a He-Ne laser of $10 \mathrm{~mW}$ with a wavelength of $632.9 \mathrm{~nm}$. The micro beam with a diameter of $2 \mu \mathrm{m}$ was moved randomly on the surface of the films to avoid local heating. The scattered radiation was collected in the region between 500 and $2000 \mathrm{~cm}^{-1}$ with $10 \mathrm{~s}$ acquisition time.

The ash content of the obtained products was determined through thermalgravimetry in a SDTQ600 TA Instruments equipment at a heating rate of $20^{\circ} \mathrm{C} \mathrm{min}^{-1}$ in $\mathrm{O}_{2}$ atmosphere. The ashes were analyzed by energy-dispersive X-ray spectroscopy (EDS) in an Energy Dispersive X-ray Spectrometer Shimadzu EDX 720 in air with Rh tube collimator and a tension of $50 \mathrm{kV}$.

Differential scanning calorimetry (DSC) analyses were carried out in a DSC-4 Perkin Elmer instrument by heating the carbons in $\mathrm{N}_{2}$ atmosphere from 40 to $400{ }^{\circ} \mathrm{C}$, cooling to $50{ }^{\circ} \mathrm{C}$ and subsequent heating to $400{ }^{\circ} \mathrm{C}$. The heating and cooling rates were $10{ }^{\circ} \mathrm{C} \mathrm{min}^{-1}$.

The wide angle X-ray (WAXRD) patterns were obtained by using a Siemens diffractometer, with $\mathrm{Cu}-\mathrm{K}_{\alpha}$ radiation $(\lambda=0.1542 \mathrm{~nm})$, Ni filter and graphite monochromator.

The morphology of these materials was obtained through scanning electron microscopy (SEM). A $50 \mathrm{~nm}$ Au film was deposited on the surface of the carbons to improve conductivity. The analyses took place in a JEOL Microscope JSM 6060 operating at $20 \mathrm{kV}$.

The specific surface area and the pore size distribution were determined through the Brunauer, Emmet and Teller $(\mathrm{BET})^{35}$ and Barret, Joyner and Halenda (BJH) ${ }^{36}$ methods, respectively. BET nitrogen isotherms were determined by physisorption of $\mathrm{N}_{2}$ at $77 \mathrm{~K}$ using a Quantachrome Autosorb 1 Instrument.
The gaseous products, responsible for the development of the specific surface area of the carbons produced through $\mathrm{KOH}$ pyrolysis process, were characterized through Fourier transform infrared (FTIR) analysis coupled with thermogravimetry. This analysis was carried out in a thermogravimetric SDTQ600 TA Instruments coupled with Thermo Nicolet 6700 FTIR by using a Q1000 interface. According to the previously described procedure, particles with diameters lower than $300 \mu \mathrm{m}$ were mixed with $\mathrm{KOH}$ in a ratio of $1: 1(\mathrm{~m} / \mathrm{m})$, stirred for $30 \mathrm{~min}$ and dried at $110^{\circ} \mathrm{C}$ for $2 \mathrm{~h}$. They were heated from 25 to $700{ }^{\circ} \mathrm{C}$ under a $\mathrm{N}_{2}$ flow with $20^{\circ} \mathrm{C} \mathrm{min}^{-1}$ heating rate. The released gases were characterized by FTIR, obtained with $4 \mathrm{~cm}^{-1}$ resolution in the range from 4000 to $500 \mathrm{~cm}^{-1}$. This method has been used for the analysis of gases produced by pyrolysis of wastes. ${ }^{37}$

The dye removing capacity was tested for concentrations varying from 2 to $200 \mathrm{mg} \mathrm{L}^{-1}$ for methylene blue and concentrations varying from 2 to $40 \mathrm{mg} \mathrm{L}^{-1}$ for methyl orange. For both dyes, the system carbon per dye solution, $1.5 \mathrm{~g}$ carbon per $50 \mathrm{~mL}$ dye solution, was stirred for $1 \mathrm{~h}$, centrifuged at $5000 \mathrm{rpm}$ during $20 \mathrm{~min}$ and subsequently filtered in a $0.45 \mu \mathrm{m}$ poly(tetrafluorethylene) filter. This filter was chosen to minimize the interactions with the system and to avoid competition with carbon to remove dye from solution.

The carbon adsorption capacity as a function of time was characterized for methylene blue dye, by adding activated carbon to a $15 \mathrm{mg} \mathrm{L}^{-1}$ methylene blue dye solution ( $3 \mathrm{~g}$ carbon per $100 \mathrm{~mL}$ solution). The system was stirred at different times and subsequently filtered in a $0.45 \mu \mathrm{m}$ polytetrafluorethylene filter.

The measurements described here took place at $\mathrm{pH} 7.0$ at $25{ }^{\circ} \mathrm{C}$ and the final concentration was measured as function of UV-Vis absorbance ( $660 \mathrm{~nm}$ for methylene blue and $450 \mathrm{~nm}$ for methyl orange solutions) in a T80 UV/Vis Spectrometer PG Instruments Ltd.

\section{Results and Discussion}

\section{Yielding and thermal stability of the products}

The pyrolysis of the treads of tire wastes, in presence of $\mathrm{KOH}$ and $\mathrm{ZnCl}_{2}$, under $\mathrm{N}_{2}$ flow, gives approximately $50 \%$ yield (Table 1 ).

Thermal stability is an important factor when dealing with environmental questions, and good adsorbents have to be stable under heating and not release in the ambient decomposition products. The DSC thermograms, Figures 1 and 2, show that the pyrolysis products are stable in a temperature range from 40 to $400{ }^{\circ} \mathrm{C}$. The resulting product of the tire activation with $\mathrm{KOH}$, Figures 1a and $1 \mathrm{~b}$, 
presents an endothermic transition at $80{ }^{\circ} \mathrm{C}$ in the first heating. This endothermic transition was not observed when the samples were re-heated. Also, an endothermic transition at $58{ }^{\circ} \mathrm{C}$ was observed for the carbons obtained through $\mathrm{ZnCl}_{2}$ activation at $500{ }^{\circ} \mathrm{C}$ (Figure 2a), disappearing at the second heating. Carbons obtained with $\mathrm{ZnCl}_{2}$ at $700{ }^{\circ} \mathrm{C}$ (Figure 2b) do not show these transitions. The observed transitions can be attributed to the release of volatile products adsorbed by these carbons from the ambient, such as hydrocarbon, water etc. This is a good indicative of the performance of these carbons which act as gas adsorbents. ${ }^{6}$

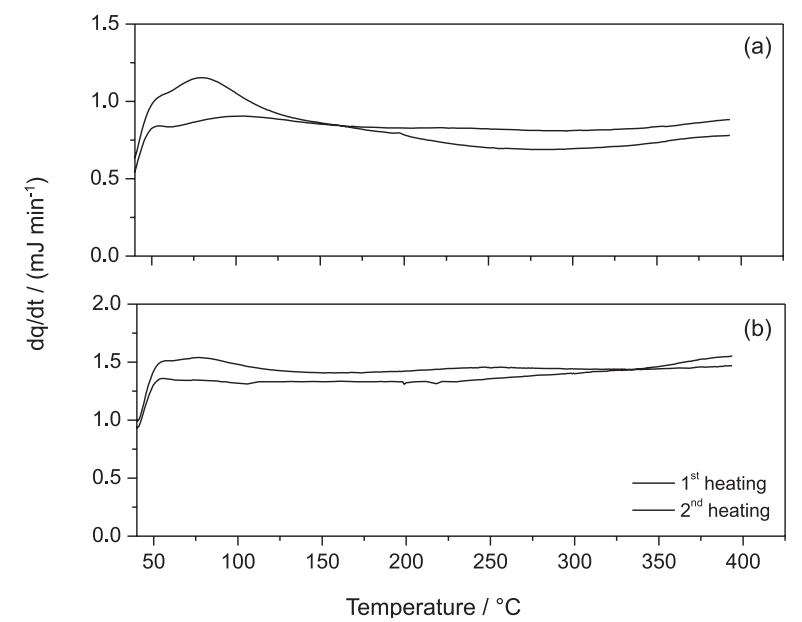

Figure 1. Differential scanning calorimetry thermograms obtained in $\mathrm{N}_{2}$ atmosphere at $10^{\circ} \mathrm{C} \mathrm{min}^{-1}$ for carbons obtained with $\mathrm{KOH}$ as activating agent at: a) $500^{\circ} \mathrm{C}$ and b) $700^{\circ} \mathrm{C}$ pyrolysis temperature.

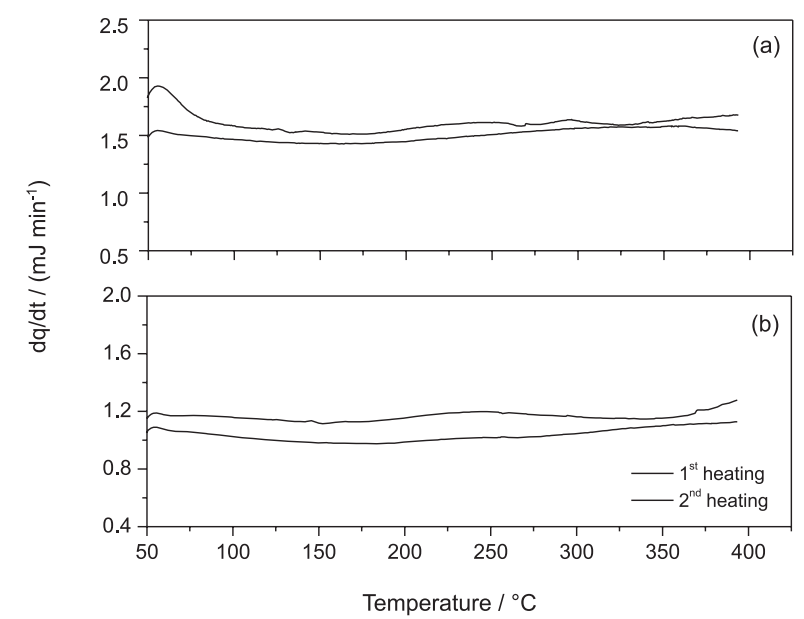

Figure 2. Differential scanning calorimetry thermograms obtained in $\mathrm{N}_{2}$ atmosphere at $10^{\circ} \mathrm{C} \mathrm{min}^{-1}$ for carbons obtained with $\mathrm{ZnCl}_{2}$ as activating agent at: a) $500^{\circ} \mathrm{C}$ and b) $700^{\circ} \mathrm{C}$ pyrolysis temperature.

\section{Chemical and structural characterization}

The original tire threads present $3.5 \%$ ashes content, which are composed mainly of silicon and zinc. The EDS analyses, performed on the ashes of the obtained carbons,
Table 2, show that the activating agents are partially removed during pyrolysis and posterior acid treatment. Zinc and sulfur, however, are still present. These elements are not desirable in an aqueous environment and could be an additional problem in using these products as adsorbents.

Table 2. Elements present in the ashes of the obtained carbons. The values were normalized by the majority inorganic elements present in each sample: potassium for samples 1 and 3, chloride for sample 2 and sulfur for sample 4

\begin{tabular}{lccccc}
\hline \multirow{2}{*}{$\begin{array}{l}\text { Sample } \\
\text { number }\end{array}$} & $\begin{array}{c}\text { Activating agent } \\
\text { pyrolysis } \\
\text { temperature }\left({ }^{\circ} \mathrm{C}\right)\end{array}$ & Sulfur & Zinc & Potassium & Chloride \\
\cline { 3 - 6 } & $\mathrm{KOH} / 500$ & 0.16 & 0.04 & 1.0 & 0.13 \\
2 & $\mathrm{ZnCl}_{2} / 500$ & 0.38 & 0.41 & 0.20 & 1.0 \\
3 & $\mathrm{KOH}_{2} / 700$ & 0.24 & 0.04 & 1.0 & - \\
4 & $\mathrm{ZnCl}_{2} / 700$ & 1.0 & 0.17 & 0.46 & 0.88 \\
\hline
\end{tabular}

However, tests performed with water and acid solutions, which were in contact with these carbons, are negative for $\mathrm{Zn}^{2+}$ and $\mathrm{S}^{2-}$ ions. The presence of $\mathrm{Zn}^{2+}$ in water was tested by using a $0.1 \mathrm{~mol} \mathrm{~L}^{-1}$ potassium hexacyanoferrate (II) solution that would result in a white precipitate. ${ }^{38}$ To test the presence of sulfur $\mathrm{S}^{2-}$, it was used a solution of $0.5 \mathrm{~mol} \mathrm{~L}^{-1}$ lead acetate which would provide a black precipitate. ${ }^{38}$ This result show that zinc and sulfur elements, even part of carbon structure, cannot be released as sulfide and zinc ions solely through the contact between this material and water or acid solutions, since both are soluble in acid media. This irreversible attachment of zinc and sulfur in the carbon structure prevents the contamination of the aqueous environment, where this carbon can be used as adsorbent. The structural characteristic of these carbons are presented in WAXRD diffractograms (Figure 3).

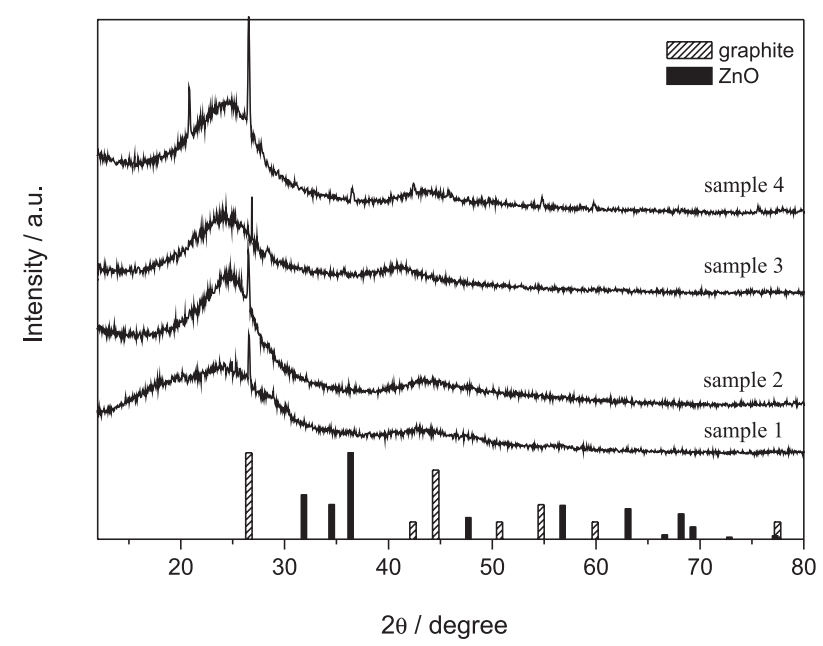

Figure 3. X-ray diffractograms of the obtained products (according Table 1) with $\mathrm{Cu}-\mathrm{K}_{\alpha}=0.1542 \mathrm{~nm}$. The spectra are shifted to permit the comparison. 
All the diffratograms are characterized by broad bands around $25^{\circ}$, which is attributed to amorphous carbon (with $\mathrm{sp}^{2}$ and $\mathrm{sp}^{3}$ hybridization). Also, the presence of peaks with a maximum at $26.5^{\circ}$ and broad bands at $42.5^{\circ}$ are attributed to the (002) plane and a superposition of the planes 100 and 101 of the graphite structure. ${ }^{39}$

Graphite interplanar distance is around $0.335 \mathrm{~nm}$ and corresponds to the values of the carbons prepared in this work. The products obtained with $\mathrm{KOH}$ at $500^{\circ} \mathrm{C}$ (sample 1, Table 1) show high amounts of amorphous carbon. The zinc oxide, which is present in the original rubber composition, is not observed in the diffractograms. ${ }^{40}$ The presence of polycyclic aromatic hydrocarbons (PAHS), environmental hazardous materials, are detected in sample 4 , through the $2 \theta$ peak at $20.8^{\circ} .^{41}$

The micro-Raman spectra, in Figure 4, show D bands, between 1338 and $1367 \mathrm{~cm}^{-1}$ and $\mathrm{G}$ bands appearing from 1589 to $1593 \mathrm{~cm}^{-1}$ for all obtained products. Graphitic single crystals produce a single $\mathrm{G}$ peak at $1575 \mathrm{~cm}^{-1} .^{42}$ Samples 1, 2 and 4 present well defined graphitic peaks, according to the WAXRD results. The origin of the D band is still a matter of discussion. Castiglioni et al. ${ }^{43}$ suggested that the D band arises from the activation of specific phonons localized in $\mathrm{sp}^{2}$ domains with dimensions of a few nanometers. These specific phonons are confined by the disorder of the graphitic structure and can also be attributed to the amorphous carbon structure. ${ }^{43}$ All samples present large $\mathrm{D}$ bands. The presence of fluorescence is observed for polycyclic aromatic hydrocarbons..$^{43}$ Raman results are in agreement with WAXRD results and confirm the presence of s poly aromatic hydrocarbon in sample 4 .

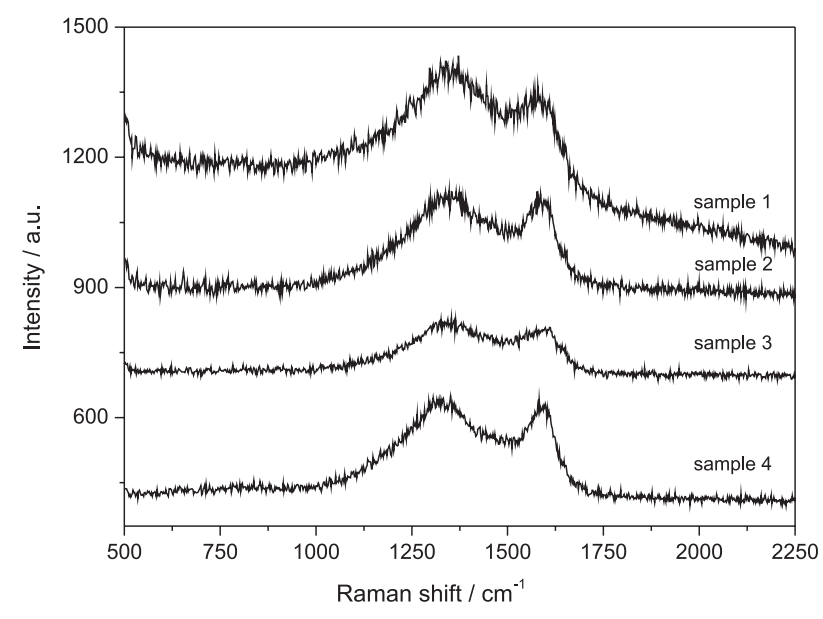

Figure 4. Micro-Raman spectra of the samples prepared according Table 1. The spectra are shifted to permit the comparison.

The carbons particles are very similar when analyzed through scanning electron micrography, independent of the conditions through which they were obtained. Figure 5 is representative of these morphologies and shows spherical nanometric particles that aggregate.

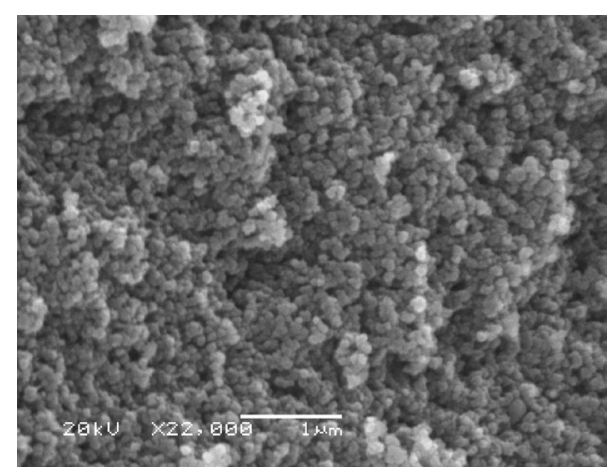

Figure 5. SEM $20 \mathrm{kV}$ of the sample 3 , carbon obtained with $\mathrm{KOH}$ as activating agent and pyrolyzed at $700{ }^{\circ} \mathrm{C}$.

Influence of the activating agent and temperature on the specific surface area and pore size distribution

High specific surface area is one requisite for obtaining good adsorbents. However, the pore size and pore size distribution, as well as the size of the dye to be removed, have to be considered. ${ }^{27}$ The specific surface areas of the samples, determined through the BET method ${ }^{35}$ and the pore size and $\mathrm{d} V_{p} / \mathrm{d} D_{p}$, determined through the $\mathrm{BJH}$ method $^{36}$ from desorption branch of the isotherms, are displayed in Table 3.

Table 3. Surface properties of the produced adsorbents obtained through the BET and BJH methods, $D_{p}$ : average pore diameter and $V_{p}$ : volume adsorption

\begin{tabular}{lccc}
\hline Sample & $\begin{array}{c}\text { BET specific surface } \\
\text { area } /\left(\mathrm{m}^{2} \mathrm{~g}^{-1}\right)\end{array}$ & $D_{p} / \mathrm{nm}$ & $\begin{array}{l}\mathrm{d} V_{p} / \mathrm{d} D_{p} / \\
\left(\mathrm{cm}^{3} \mathrm{~g}^{-1}\right)\end{array}$ \\
\hline 1 & 49.6 & 3.7 & $8.7 \times 10^{-2}$ \\
2 & 183 & 3.0 & $4.0 \times 10^{-1}$ \\
3 & 502 & 3.2 & $3.1 \times 10^{-1}$ \\
4 & 212 & 2.8 & $5.9 \times 10^{-1}$ \\
\hline
\end{tabular}

The triturated thread of tire presents the smallest specific surface area $\left(9.4 \mathrm{~m}^{2} \mathrm{~g}^{-1}\right)$. Pyrolysis temperature plays an important role on $\mathrm{KOH}$ activation. The carbons produced through activation with zinc chloride, at 500 and $700{ }^{\circ} \mathrm{C}$, present a similar specific surface area. The development of the specific surface area can be related with the gas evolution during the pyrolysis. ${ }^{26}$

TGA/FTIR coupled analyses permitted to characterize the gaseous products responsible for the development of the specific surface area of the carbons, produced through activation with $\mathrm{KOH}$ at $700^{\circ} \mathrm{C}$, which presented the highest specific surface area (sample 3, Table 1). 


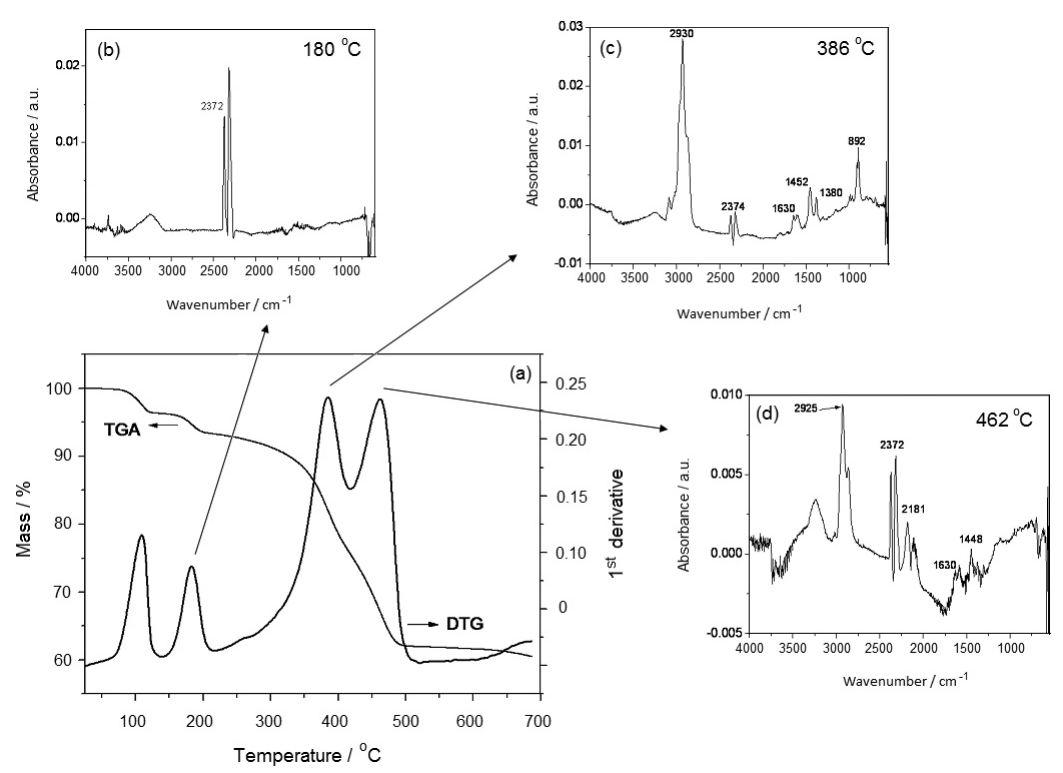

Figure 6. TGA thermogram coupled with FTIR spectra of the pyrolysis gases released at different temperatures from the treads of scrap tires, activated with potassium hydroxide in $\mathrm{N}_{2}$ atmosphere.

Since the heating was performed up to $700{ }^{\circ} \mathrm{C}$, the three FTIR spectra are intended to reproduce the gaseous products resulting from the pyrolysis process. The peak located at $100{ }^{\circ} \mathrm{C}$ in TGA is water from the sample. The main gas products in the pyrolysis of treads of tire waste are $\mathrm{CO}_{2}, \mathrm{H}_{2} \mathrm{O}, \mathrm{CO}$ and hydrocarbons. The FTIR spectra obtained at temperatures of 180,385 and $462^{\circ} \mathrm{C}$ are shown in Figure 6. Carbon dioxide generated in the pyrolysis, which presents a $v_{\mathrm{C}=\mathrm{O}}$ band around $2374 \mathrm{~cm}^{-1}$, acts as a physical activating agent. At $180{ }^{\circ} \mathrm{C}, \mathrm{CO}_{2}$ and water vapor are observed. At temperatures higher than $300{ }^{\circ} \mathrm{C}$ the presence of gases from the used chemicals in the tire production is observed. Nitrogen dioxide is released at $385{ }^{\circ} \mathrm{C}$ through a characteristic band at $892 \mathrm{~cm}^{-1}\left(\delta_{\mathrm{N}-\mathrm{O}}\right)$ and part of the sulfur, which used in rubber vulcanization, produces $\mathrm{SO}_{2}$ being observed through a band at $1380 \mathrm{~cm}^{-1}$ $\left(v_{\mathrm{S}=\mathrm{O}}\right)$. At temperatures of 385 and $462{ }^{\circ} \mathrm{C}$, hydrocarbon compounds are released and are detected through a characteristic band of methylene $\left(1452 \mathrm{~cm}^{-1}, \delta_{\mathrm{C}-\mathrm{H}}\right)$. Polystyrenes ( 1,4 polybutadiene and cis-1,2 polyisoprene) contribute to these pyrolysis gases. The loss of weight is also accompanied by the evolution of the band at $2930 \mathrm{~cm}^{-1}$ $\left(v_{\mathrm{C}-\mathrm{H}}\right)$, which depicts the degradation of the polymer with the consequent gas emissions. This resulting band of the labile material can be observed even at temperatures above $385{ }^{\circ} \mathrm{C}$. Carbon monoxide appears only at $462{ }^{\circ} \mathrm{C}$ with a characteristic signal at $2181 \mathrm{~cm}^{-1}\left(v_{\mathrm{C}=0}\right)$. At $462{ }^{\circ} \mathrm{C}$, the presence of $\mathrm{v}_{\mathrm{O}-\mathrm{H}}$ band at $3240 \mathrm{~cm}^{-1}$ and $\delta_{\mathrm{O}-\mathrm{H}} 1630 \mathrm{~cm}^{-1}$ are related to water outlet as gaseous products, which can be explained through the hydrogen capture by hydroxyl anion from the activating agent. ${ }^{44}$
Adsorption characteristics of the obtained products for methylene blue and methyl orange dyes

The performance of the produced carbons are presented in Table 1 and, for removing methyl orange and methylene blue dyes at environmental conditions of $\mathrm{pH}$ and concentrations Tables 4 and 5, respectively. The range of concentrations analyzed in this work are lower than the reported in the literature, with maxima values for adsorption of methylene blue dye in carbons obtained from tires varying from 40 to $130 \mathrm{mg} \mathrm{g}^{-1} \cdot{ }^{23}$ From both tables, the systems attain the equilibrium concentrations, which are almost the same for all range of initial concentrations and, the carbon saturation limits for adsorption were not attained in this work. It is well known that high $\mathrm{pH}$ is preferred for adsorption of methylene blue (a cathionic dye) in active carbons. ${ }^{27}$ However due to environmental concerns, it is important to characterize the capacity for removing dyes in waste water without the addition of chemicals to modify $\mathrm{pH}$ values and investigate the lower limits for removing dye.

Carbons obtained through activation with $\mathrm{KOH}$ and pyrolysis at $700^{\circ} \mathrm{C}$ allowed the nearly complete removal of the methylene blue dye (Table 5) and a lower performance in the removal of methyl orange, as shown in Table 4. The percentages of removal presented in Table 5 are similar to that obtained by Kannan and Sundaram ${ }^{45}$ for the removal of the same initial methylene blue concentration (100-200 mg L $\mathrm{L}^{-1}$ ) by coconut shell carbon. The efficiency increases with the initial concentration of dye, what is expected due to the proportional adsorption to the interaction between dye and carbon in the solution. 
Table 4. Capacity in removing methyl orange dye at different initial concentrations in $\mathrm{pH} 7.0$ at $20^{\circ} \mathrm{C}$ for carbons obtained through activation with $\mathrm{KOH}$ and pyrolysis at $700{ }^{\circ} \mathrm{C}$

\begin{tabular}{|c|c|c|c|}
\hline $\begin{array}{l}\text { Initial conc. / } \\
\left(\mathrm{mg} \mathrm{L}^{-1}\right)\end{array}$ & $\begin{array}{l}\text { Equilibrium } \\
\text { conc. / }\left(\mathrm{mg} \mathrm{L}^{-1}\right)\end{array}$ & $\begin{array}{l}\text { Adsorbed dye per } \\
\mathrm{g}_{\text {carbon } /\left(\mathrm{mg} \mathrm{g}^{-1}\right)}\end{array}$ & $\begin{array}{c}\text { Efficiency / } \\
\%\end{array}$ \\
\hline 2.00 & 0.680 & 0.044 & 66.0 \\
\hline 5.00 & 0.480 & 0.150 & 90.4 \\
\hline 10.0 & 0.650 & 0.312 & 93.5 \\
\hline 12.0 & 0.680 & 0.377 & 94.3 \\
\hline 15.0 & 0.620 & 0.478 & 95.9 \\
\hline 17.0 & 0.815 & 0.536 & 95.2 \\
\hline 20.0 & 0.640 & 0.645 & 96.8 \\
\hline 25.0 & 0.333 & 0.817 & 98.7 \\
\hline 30.0 & 0.680 & 0.971 & 97.7 \\
\hline 40.0 & 0.680 & 1.306 & 98.3 \\
\hline
\end{tabular}

Table 5. Capacity in removing methylene blue dye at different initial concentrations in $\mathrm{pH} 7.0$ at $20^{\circ} \mathrm{C}$ for carbons obtained through activation with $\mathrm{KOH}$ and pyrolysis at $700{ }^{\circ} \mathrm{C}$

\begin{tabular}{|c|c|c|c|}
\hline $\begin{array}{l}\text { Initial conc. / } \\
\left(\mathrm{mg} \mathrm{L}^{-1}\right)\end{array}$ & $\begin{array}{l}\text { Equilibrium } \\
\text { conc. / }\left(\mathrm{mg} \mathrm{L}^{-1}\right)\end{array}$ & $\begin{array}{l}\text { Adsorbed dye per } \\
\mathrm{g} \text { carbon } /\left(\mathrm{mg} \mathrm{g}^{-1}\right)\end{array}$ & $\begin{array}{c}\text { Efficiency / } \\
\%\end{array}$ \\
\hline 2.00 & 0.279 & 0.0574 & 82.4 \\
\hline 5.00 & 0.259 & 0.1580 & 93.5 \\
\hline 10.0 & 0.264 & 0.3245 & 96.7 \\
\hline 15.0 & 0.299 & 0.4900 & 97.5 \\
\hline 20.0 & 0.244 & 0.6542 & 98.5 \\
\hline 40.0 & 0.249 & 1.3250 & 99.2 \\
\hline 50.0 & 0.254 & 1.6582 & 99.4 \\
\hline 100 & 0.309 & 3.3230 & 99.6 \\
\hline 150 & 0.318 & 4.9728 & 99.7 \\
\hline 200 & 0.318 & 6.6561 & 99.8 \\
\hline
\end{tabular}

The dimension of the methyl orange dye obtained by Hyperchem ${ }^{\circledast}$ program is $0.61 \mathrm{~nm} \times 1.67 \mathrm{~nm}$ and of the methylene blue dye is $0.61 \times 1.42 \mathrm{~nm}$, both are very similar and smaller than the average pore diameters reported for obtained carbons in this work (Table 3).

Carbons produced through activation with $\mathrm{KOH}$ at $500{ }^{\circ} \mathrm{C}$, with lower specific surface area (Table 3 ) removed about $73 \%$ of $200 \mathrm{mg} \mathrm{L}^{-1}$ methylene blue dye. Carbons obtained through activation with $\mathrm{ZnCl}_{2}$ at 500 and $700{ }^{\circ} \mathrm{C}$ (samples 2 and 4 ) removed about 90 and $55 \%$ of the original dye, respectively. For these carbons, there is no direct correlation between the performance in adsorption and the specific surface area (Table 3), both samples present similar specific surface areas and the former one is more efficient in removing methylene blue. It is possible to attribute the inferior adsorption capacity of sample activated with $\mathrm{ZnCl}_{2}$ and pyrolysed at $700{ }^{\circ} \mathrm{C}$ to the smallest average pore diameter, as well as the presence of other products in this sample (PAHS, reported previously).

All results shown above were obtained after $1 \mathrm{~h}$ of contact between the carbons and the solution. With carbons obtained through the activation with $\mathrm{KOH}$ and pyrolysis at $700{ }^{\circ} \mathrm{C}$, it was obtained the time necessary to attain the maximum adsorption values for $15 \mathrm{mg} \mathrm{L}^{-1}$ of methylene blue solution. The results (Figure 7) show that about 30 $\mathrm{min}$ is sufficient for removing dye with a similar efficiency as the one obtained in Table 5 (obtained through a contact time of $1 \mathrm{~h}$ ).

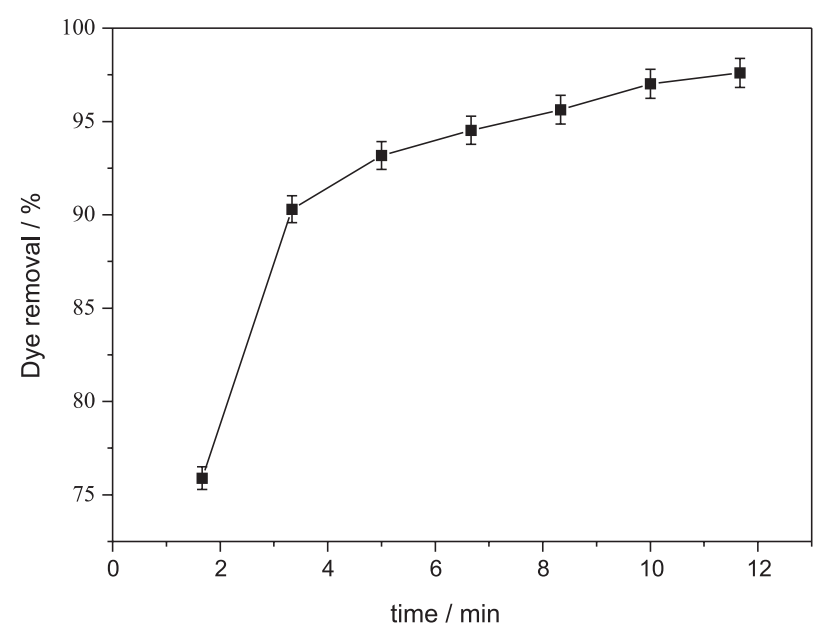

Figure 7. Capacity in removing methylene blue dye $\left(15 \mathrm{mg} \mathrm{L}^{-1}\right)$ as function of time at $20^{\circ} \mathrm{C}$ and $\mathrm{pH} 7.0$ for carbons obtained through activation with $\mathrm{KOH}$ and pyrolysis at $700{ }^{\circ} \mathrm{C}$.

\section{Conclusions}

In this work we obtained active carbons from a specific region of tires, the threads, composed mainly of rubber and good quality carbon black, through chemical recycling with $\mathrm{KOH}$ and $\mathrm{ZnCl}_{2}$, pyrolyzed at 500 and $700{ }^{\circ} \mathrm{C}$.

The products present a mesoporous structure and contain zinc and sulfur which are not released when these carbons are placed in contact with water or acid solutions.

The carbons obtained with $\mathrm{ZnCl}_{2}$ as activating agent, at both temperatures, present a graphitic structure and almost the same specific surface area. Higher temperature zinc chloride activated carbon presents polycyclic aromatic hydrocarbons, which are hazardous materials to be used in waste water treatment. Also, the adsorption for methylene blue is better in the material obtained at lower temperatures.

It was also identified that temperature is important for the activation of the threads of tire waste with $\mathrm{KOH}$, improving the specific surface area, as well as the adsorption behavior. The products generated during pyrolysis process, such as carbon dioxide, water vapor and carbon monoxide, 
were characterized as responsible for the development of the specific surface area.

Even though some authors emphatically report the importance of high specific surface areas to validate their process of carbon production, the specific surface area is not the only important factor. The relation between the size of the dye and the diameter of pores is a factor that has to be considered. Methylene blue and methyl orange dyes have similar dimensions to the produced carbons average pore diameter. Pore size distribution, $\mathrm{pH}$ of the medium and time of contact are important factors to define a good material for waste water treatment.

Carbons produced through $\mathrm{KOH}$ activation present small pore size distribution and efficiently adsorb these dyes even at $\mathrm{pH} 7.0$, permitting the removal of these dyes without strong modifications in the waste water $\mathrm{pH}$.

\section{Acknowledgments}

This work is supported by Conselho Nacional de Desenvolvimento Científico e Tecnológico (CNPq) and Fundação de Apoio a Pesquisa do Estado do Rio Grande do Sul (FAPERGS).

\section{References}

1. Blackman, A.; Palma, A.; J. Environ. Dev. 2002, 11, 247.

2. Smith, A. P.; Ade, H.; Koch, C. C.; Spontak, R. J.; Polymer 2001, 42, 4453.

3. Yuen, F. K.; Hameed, B. H.; Adv. Colloid Interface Sci. 2009, 149, 19.

4. Adhikari, B.; De, D.; Maiti, S.; Prog. Polym. Sci. 2000, 25, 909.

5. Rodriguez, I. M.; Laresgoiti, M. F.; Cabrero, M. A.; Torres, A.; Chomón, M. J.; Caballero, B.; Fuel Process. Technol. 2001, 72,9 .

6. Tripathy, A. R.; Williams, D. E.; Farris, R. J.; Polym. Eng. Sci. 2004, 44, 1338.

7. Domínguez-Vargas, J. R.; Navarro-Rodriguez, J. A.; de Heredia, J. B.; Cuerda-Correa, E. M.; J. Hazard. Mater. 2009, 169, 302.

8. Sun, J.; Brady, T. A.; Rood, M. J.; Lehmann, C. M.; RostamAbadi, M.; Lizzio, A. A.; Energy Fuels 1997, 11, 316.

9. Ariyadejwanich, P.; Tanthapanichakoon, W.; Nakagawa, K.; Muka, S. R.; Tamon, H.; Carbon 2003, 41, 157.

10. Tanthapanichakoon, W.; Ariyadejwanich, P.; Nakagawa, K.; Mukai, S. R.; Tamon, H.; Water Res. 2005, 39, 1347.

11. Mui, E. L. K.; Cheung, W. H.; McKay, G.; J. Hazard. Mater. 2010, 175, 151.

12. Mui, E. L. K.; Cheung, W. H.; Valix, M.; McKay, G.; Microporous Mesoporous Mater. 2010, 130, 287.

13. Vanhulle, S.; Trovaslet, M.; Enaud, E.; Lucas, M.; Taghavi, S.; van der Lelie, D.; van Aken, B.; Foret, M.; Onderwater, R. C. A.;
Wesenberg, D.; Agathos, S. N.; Scheneider, Y.; Corbisier, A.; Environ. Sci. Technol. 2008, 42, 584.

14. Lin, Y. R.; Teng, H.; Microporous Mesoporous Mater. 2002, 54 , 167.

15. Garcia, I. T. S.; Nunes, M. R.; Carreño, N. L. V.; Wallaw, W. M.; Fajardo, H. V. ; Probst, L. F. D.; Polímeros 2007, 17, 329.

16. Mui, E. L. K.; Ko, D. C. K.; Mckay, G.; Carbon 2004, 42, 2789.

17. Teng, H.; Lin, Y. C.; Hsu, L. Y.; J. Air Waste Manage. Assoc. 2000, 50, 1940.

18. Manchon-Vizuete, E.; Macias-Garcia, A.; Gisbert, A. N.; Fernandez-Gonzalez, C.; Gomez-Serrano, V.; Micros. Mes. Mater. 2004, 67, 35.

19. Suuberg, E. M.; Aarna, I.; Carbon 2007, 45, 1719.

20. González, J. F.; Encinar, M.; González-García, M.; Appl. Surf. Sci. 2006, 252, 5999.

21. Zabaniotou, A.; Madau, P.; Oudenne, P. D.; Jung, C. G.; Delplancke, M. P.; Fontana, A.; J. Anal. Appl. Pyrolysis 2004, 72, 289.

22. Cataldo, F.; Macromol. Mater. Eng. 2005, 290, 463.

23. Helleur, R.; Popovic, N.; Ikura, M;. Stanciulescu, M; Liu, D.; J. Anal. Appl. Pyrolysis 2001, 58, 813.

24. Betancur, M.; Martínez, J. D.; Murillo, R.; J. Hazard. Mater. 2009, 168, 882.

25. Skodras, G.; Diamantopoulou, I. R.; Zabaniotou, A.; Stavropoulo, G.; Sakellaropoulos, G. P.; Fuel Process. Technol. 2007, 88, 749.

26. Ioannidou, O.; Zabaniotou, A.; Renewable Sustainable Energy Rev. 2007, 11, 1966.

27. Royer, B.; Cardoso, N. F.; Lima, E. C.; Vaghetti, J. C. P.; Simon, N. M.; Calvete, T.; Veses, R. C.; J. Hazard. Mater. 2009, 164, 1213.

28. Rios, R. R. V. A; Gontijo, M.; Ferraz, V. P.; Lago, R. M.; Araujo, M. H.; J. Braz. Chem. Soc. 2006, 17, 603.

29. Zhou, J.; Yu, T.; Wu, S.; Xie, Z.; Yang, Y.; Ind. Eng. Chem. Res. 2010, 49, 1691.

30. Hamadi, N. K.; Swaminathan, S.; Chen, X. D.; J. Hazard. Mater. 2004, 112, 133.

31. Ucar, S.; Karagoz, S.; Ozkan, A. R.; Yanik, J.; Fuel 2005, 84, 1884.

32. Gupta, V. K.; Suhas, I.; Ali, V. K. Ind. Eng. Chem. Res. 2004, 43,1740 .

33. Janos, P.; Environ. Sci. Technol. 2003, 5792.

34. Gupta, V. K.; Suhas, I.; J. Environ. Manage. 2009, 90, 2313.

35. Brunauer, S.; Emmet, H.; Teller, E.; J. Am. Chem. Soc. 1938, $60,309$.

36. Barrett, E. P.; Joyner, L. G.; Halenda, P. P.; J. Am. Chem. Soc. 1951, 73, 373.

37. Tao, L.; Zhao, G.; Qian, J.; Qin, Y.; J. Hazard. Mater. 2010 , $175,754$.

38. Svehla, G.; Vogel's Textbook of Macro and Semimicro Qualitative and Inorganic Analysis, $5^{\text {th }}$ ed.; Logman Group Limited: London, 1979.

39. Debye, P.; Scherrer, P.; Phys. Z. 1916, 17, 277. 
40. Bates, C. H.; White, W. B.; Roy, R.; Science 1962, 137, 993.

41. Mace, A. H.; Peterson, R. C.; Can. Mineral. 1995, 33, 7.

42. Tuinstra, F.; Koenig, J. L.; J. Chem. Phys. 1970, 53, 1126.

43. Castiglioni, C.; Mapelli,C.; Negri, F.; Zerbi, G.; J. Chem. Phys. 2001, 114, 963.
44. Jiang, X.; Li, C.; Wang, T.; Liu, B.; Chi, Y.; Yan, J.; J. Anal. Appl. Pyrolysis 2009, 84, 103.

45. Kannan, N.; Sundaram, M. M.; Dyes and Pigments 2001, 51, 25.

Submitted: March 4, 2011

Published online: August 23, 2011 